\title{
Publicações Redundantes ou Duplicadas / Aceitabilidade de Uma Publicação Secundária
}

$\mathrm{E}^{\mathrm{s}}$ STAVA RETOCANDO UM EDITORIAL que abordava tema totalmente diverso, quando, há algumas semanas, recebi do Prof. Geraldo Medeiros-Neto uma correspondência na qual ele me chamava à atenção dados extraídos do "Uniform Requirements for Manuscripts Submitted to Biomedical Journals", publicado pelo International Committee of Medical Journal Editors (ICMJE) (1).

Conforme mencionado em sua carta, estes dados já eram, certamente, de meu conhecimento e até fazem parte da política editorial que os "Arquivos" vem adotando em consonância com as diretrizes do ICMJE; as revistas que concordan com o uso dos "Uniform Requirements" são apenas solicitadas a citar este documento de 1997 em suas instruções para os autores. Esta prática vem sendo adotada hoje em dia por significativa parcela (mais de 500) de revistas científicas publicadas no mundo todo.

Concordamos, porém, que a divulgação destes dados devesse ser de interesse e utilidade para os nossos leitores, razão pela qual transcrevo abaixo - com tradução literal minha e desculpas pela tecnicalidade do texto extratos das normas do ICMJE que tratam especificamente do tema em refcrência, e que foram também recentemente republicadas no São Paulo Medical Journal / Revista Paulista de Medicina (2):

"PUBLICAÇÃO REDUNDANTE OU DUPLICADA é a publicação de um manuscrito que se sobrepõc substancialmente a outro previamentc publicado.

Leitores de periódicos de fonte primária merecem ser capazes de confiar na originalidade daquilo que eles estão lendo, a menos que haja uma declaração evidente de que o artigo esteja sendo republicado por escolha do autor $\mathrm{e}$ do editor. As bases para esta posição são as leis internacionais de direito de cópia (copyright), conduta ética, e a relação custo-efetividade dos recursos.

A maioria das revistas não deseja receber manuscritos sobre trabalhos que já tenham sido reportados em grande parte $\mathrm{cm}$ outro artigo já publicado ou que estejam contidos em artigo que tenha sido submetido ou aceito para publicação em outra revista, seja em meio impresso ou eletrônico. Esta política não impede a revista de considerar um manuscrito que tenha sido rejeitado por outra revista, ou um artigo completo que se segue à publicação dos dados de forma preliminar, como um resumo (abstract) ou poster exposto para colegas em uma reunião profissional. Tão pouco impede que revistas possam considerar um manuscrito que tenha sido apresentado em um encontro científico mas ainda não publicado in totum ou que esteja sendo considerado para publicação em livro de resumos/anais (proccedings) ou em formato semelhante. Notas de imprensa (press reports) de reuniōes programadas não são usualmente entendidas como quebras desta regra, mas estas
Claudio E. Kater

Editor-Chefe, $A B E \mho M$ 
notas também não deverão ser ampliadas pela adição de outros dados ou cópias de tabelas e ilustraçōes.

Ao submeter um manuscrito, o autor deverá sempre informar claramente ao editor a respeito de todas as submissões e publicaçōes prévias que possam ser consideradas como publicações redundantes ou duplicadas de un mesmo trabalho ou de trabalho muito similar. 0 autor deverá alertar o editor sempre que o trabalho incluir indivíduos que já tenham sido reportados numa publicaçăo anterior. Qualquer trabalho deste tipo deverá ser mencionado e estar referido neste novo artigo. Cópias deste material deverăo scr anexadas ao artigo que está sendo submetido para auxiliar o editor na decisão de como resolver esta questão.

Na tentativa ou ocorrência de uma publicação redundante ou duplicada sem esta notificação prévia, os autores deverão esperar que alguma ação seja tomada pelos editores. No mínimo deve-se esperar a rejeição imediata do manuscrito ora submetido. Se o cditor não estava consciente desta violação, e o artigo já tiver sido publicado, então uma nota de publicação redundante ou duplicada possivelmente deverá ser publicada com ou sem a explicação ou aprovação do autor.

A liberação preliminar, usualmente para a mídia popular, de informações científicas descritas $\mathrm{cm}$ um artigo que tenha sido aceito mas ainda não publicado viola a política editorial de muitas revistas. Em alguns poucos casos, c somente após acertos com o editor, a liberação preliminar de dados poderá ser accitável - por exemplo, se houver uma situaçăo de emergência em saúde pública".

\section{ACEITABILIDADE DE UMA PUBLICAÇÃO SECUNDÁRIA}

"A publicação secundária numa mesma ou em outra língua, especialmente em outros países, é justificável, e pode ser benéfica, desde que todas as seguintes condições sejam satisfeitas:

1. Os autores tenham recebido aprovação dos editores de ambas as revistas; o editor responsável pela publicação secundária deverá obrigatoriamente ter uma fotocópia, "reprint", ou o manuscrito da versão primária do artigo.

2. A prioridade da publicação primária ć respeitada com um intervalo de pelo menos uma semana até a segunda publicação (a menos que especificamente negociado de outra forma com ambos os editores).
3. O artigo da publicação secundária é direcionado para um grupo diferente de leitores; uma versão abreviada pode ser suficiente.

4. A versão secundária reflete fielmente os dados e interpretações da versão primária.

5. Um rodapé na página título da versão secundária deve informar aos leitores, colegas, e agências de documentação que o artigo já foi publicado no todo ou em parte e mencionar a referência primária. Ou então, um rodapé razoável deverá trazer a seguinte informação: "Este artigo é baseado em um estudo publicado previamente em [nome da revista, com a referência completa]".

A permissão para esta publicação secundária deverá ser gratuita."

Ao terminar gostaria de comentar com os leitores que as normas acima mencionados não me parecem nada mais do que fundamentos do mais simples bom senso e da boa conduta ética, devendo visar - mais do que a vaidade pessoal e as pretensöes acadêmicas de um determinado autor ou grupo -, o interesse primordial dos profissionais em saúde por novas informações médico-científicas e, mais do que isso, a população necessitada de tais conquistas. Para tanto (c somente por isso) podem ser justificadas as eventuais publicações secundárias, na medida que - adequada e claramente informadas e autorizadas -, poderão ampliar a possibilidade de atingir outros e mais leitores, que poderão se beneficiar destes conhecimentos e que de outra forma não estariam expostos àquelas informaçôes.

Embora o editor e o conselho editorial se mantenham atentos à possibilidade de publicaçõcs indevidamente redundantes ou duplicadas en nossa revista, este trabalho de vigilância costuma não ser suficientemente completo para detectar toda c qualquer anormalidade. Reforço, assim, a parcela da responsabilidade que cabe aos leitores $\mathrm{c}$, principalmente, aos autores prospectivos dos $A B E \& M$, no sentido de coibirem eventuais desejos inconfessos e arroubos acadêmicos inadequados, em respeito às normas éticas e científicas que norteiam nossas sociedades afiliadas.

\section{REFERÊNCIAS}

1. Uniform Requirements for Manuscripts Submitted to Biomedical Journals. "International Committee of Medical Journal Editors" (ICMJE). N Engl J Med 1997;336(4):309-15.

2. Notes for Authors - ICMJE. São Paulo Med J / Rev Paul Med 1999; 117(1):40-1. 